\section{Türkiye'de Para Politikasının Risk Alma Kanalı: T-FAVAR Yönteminden Yeni Asimetrik Bulgular}

\author{
Ugur Akkoc $^{\mathrm{a}}$, Onder Ozgur ${ }^{\mathrm{b}}$
}

Öz: 2008 krizi sonrasında keşfedilen parasal aktarım mekanizmalarından risk alma kanalı, faiz indirimlerinin bankaların risk alma davranışlarında yarattığı değişikliklerle ekonomide etkili olduğunu savunmaktadır. Bu çalışma, Türkiye para politikasında risk alma kanalının etkinliğini, ilk kez önerilen Eşik FAVAR (T-FAVAR) yöntemi ile incelemektedir. Çalışmanın temel amacı gelişmekte olan ekonomilerden biri olan Türkiye'de düşük faiz dönemlerinde bankaların risk algılarında değişiklik olup olmadığını ortaya koymak ve böylelikle düşük politika faizlerinin finansal dengesizlikler meydana getirip getirmediğini incelemektir. Risk alma kanalının faiz rejimlerine göre asimetrik yapısını geniş veri seti yardımıyla analiz ederek literatüre katkı sağlamaktadır. Bu bağlamda, bu çalışmada Türkiye ekonomisinde risk alma kanalının varlığı 19 mevduat bankasının çeyrek dönem verileri kullanılarak 2003:Q1-2019:Q2 dönemi için araştırılmıştır. Iki farklı risk ölçütünün kullanılı̆̆ı çalışmada, Türkiye ekonomisinde 2003 sonrasında risk kanalının etkin biçimde çalıştığını destekleyen bulgular elde edilmiştir. Faiz indirimi biçimindeki genişletici para politikasının ve döviz kuru şoklarının finansal istikrarı bozucu maliyetleri olduğu ve bu maliyetlerin yüksek faiz ortamında daha kuvvetli olduğu saptanmıştır.

\section{Risk-Taking Channel of Monetary Policy in Turkey: New Asymmetric Evidences from Threshold FAVAR}

Abstract: Risk taking channel of monetary policy claims that interest rate reductions have an impact on the economy via risk taking behaviour of banks. This study investigates the effectiveness of the risk-taking channel in Turkey using a Threshold FAVAR (T-FAVAR) model. The main aim of the study is to examine whether there is a change in the risk perception of banks in the low interest regime and thereby low policy rates lead to financial instability. We aim to contribute to the relevant literature by analyzing the risk-taking channel in two different regimes, determined by high and low interest rates. In this context, this study uses quarterly data for 19 Turkish commercial banks for the time period between 2003: Q1 and 2019: Q2. We conclude that the risktaking channel is fairly strong in Turkish economy after 2003. Interest rate reductions and exchange rate shocks cause financial instability, and these effects are stronger in the high interest rate regime.
Anahtar Sözcükler: Para Politikası, Risk Alma Kanalı, T-FAVAR, Etki-Tepki Fonksiyonları

JEL: C32, E52, G21

$\begin{array}{ll}\text { Geliş } & : \text { 18 Ocak } 2021 \\ \text { Düzeltme } & : 01 \text { Mart } 2021 \\ \text { Kabul } & : 05 \text { Nisan } 2021 \\ & \\ \text { Tür } & \text { : Araştırma }\end{array}$

Keywords: Monetary Policy, Risk-Taking Channel, TFAVAR, Impulse-Response Functions

JEL: C32, E52, G21

Received : 18 January 2021 Revised : 01 March 2021 Accepted : 05 April 2021

Type : Research

a Asst. Prof., PhD., Pamukkale University, Faculty of Economics and Administrative Sciences, Department of International Trade and Finance, Denizli, Turkiye, uakkoc@pau.edu.tr (ORCID ID: 0000-0002-9949-2097)

b Res. Asst., PhD., Ankara Yildirim Beyazit University, Faculty of Political Sciences, Department of Economics, Ankara Turkiye, oozgur@ybu.edu.tr (ORCID ID: 0000-0001-5221-4842) 


\section{Giriş}

2008 küresel finansal krizi sonrasında merkez bankaları faizlerini oldukça düşürmekle birlikte bu politikalarını uzun süredir devam ettirmektedirler. Bu dönemde düşen faizlerle birlikte oluşan likidite bolluğu ve gevşeyen banka gözetimi bankaları daha riskli varlıkları finanse etme konusunda cesaretlendirmiştir (Angeloni vd., 2015: 285). Böylece, son yıllarda para politikası ile bankaların risk alma davranışları arasındaki ilişki akademisyenlerin ve politika yapıcıların ilgisini çekmeye başlamıştır (Chen vd., 2017: 116).

Para politikasında meydana gelen değişimlerin doğrudan veya dolaylı olarak bankaların risk algılarını değiştirerek risk alma davranışlarını etkilemesi süreci Borio ve Zhu (2008:2) tarafından yeni bir parasal aktarım mekanizması olarak "risk alma kanalı" şeklinde isimlendirilmiştir. Risk alma kanalı risk birikimi ve iş çevrimlerine etki ederek parasal aktarım mekanizmalarından olan kredi kanalının nasıl geliştirilebileceğini açıklamaktadır (Lopez vd., 2011: 215).

Faizlerin oldukça düşük seyretmesi bankaların risk alma iştahlarını çeşitli mekanizmalar aracılığıyla arttırmaktadır. Bunlardan ilki "getiri arama" ile ilgilidir. Düşük faiz ortamında kar marjları düşen bankalar daha riskli yatırımlara yönelerek daha yüksek getiri aramaktadırlar (Rajan, 2006: 525). Piyasada gerçekleşen faiz oranı ile hedeflenen getiri arasındaki fark açıldıkça getiri arama çabasının kuvvetlendiği görülmektedir. íkinci olarak, düşük faiz koşulları bankaların gelirlerini ve nakit akımlarını iyileştirdiğinden bankaların risk algılarını etkileyebilmektedir (Gambacorta, 2009: 43). Bu mekanizmada faiz oranları banka varlıklarının değerlemesini etkileyerek risk algısını düşürmektedir.

Üçüncüsü, düşen faizlerle birlikte yükselen varlık fiyatları bankaların teminat değerlerini artırmaktadır. Böylelikle kredilerin temerrüt olasılığı ve bankaların ölçülen riski azalmaktadır (Altunbas vd., 2010: 7). Bir diğer mekanizmada ise merkez bankalarının süregelen düşük faiz ortamında daha şeffaf politikalar izlemesinin finansal riskleri bertaraf ederek bankaları risk almaya teşvik edeceği savunulmaktadır (Alzuabi vd., 2017: 4).

$\mathrm{Bu}$ bağlamda para politikası otoritelerince küresel finansal kriz ile mücadele etmek amacıyla oluşturulan düşük faiz ortamının varlık fiyatlamaları ve risk algılarını etkileyerek finansal piyasalarda dalgalanmalar ve dengesizlikler meydana getirdiği savunulmuştur (Gaggl ve Valderrama, 2010: 32). Küresel finansal kriz sonrasında merkez bankalarının faiz politikaları ile finansal istikrar ilişkisi halen süregelen bir tartışma olarak karşımıza çıkmakta ve bu ilişkinin altında yatan mekanizmanın incelenmesi oldukça önemli hale gelmektedir (De Moraes vd., 2016: 177).

Türkiye ekonomisi, 2000 ve 2001 krizleriyle gecelik faiz oranlarının dört haneli değerlere ulaştığı bir dönem yaşamıştır (Akıncı vd., 2012: 5). Takip eden dönemde uygulamaya konulan "Güçlü Ekonomiye Geçiş Programı" ve "Bankacılık Sektörü Yeniden Yapılandırma Programı" ile gerek merkez bankacılı̆ında gerekse bankacılık sektöründe bir dizi önlem alınmış ve finansal istikrarın sağlanmasına çalışılmıştır. Bu uygulamaların sonuç vermesiyle merkez bankası politika faizlerinde de kayda değer düşüş kaydedilmiştir. Böylelikle Türkiye ekonomisi risk alma kanalının varlığına yönelik analizler için iyi bir laboratuvar imkânı sunmaktadır.

Bu bağlamda, bu çalışmada Türkiye ekonomisinde risk alma kanalının varlığı 19 mevduat bankasının çeyreklik verileri kullanılarak 2003:Q1-2019:Q2 dönemi için araştırıımıştır. Çalışmanın temel amacı gelişmekte olan ekonomilerden biri olan Türkiye'de düşük faiz dönemlerinde bankaların risk algılarında değişiklik olup olmadığını ortaya koymak ve böylelikle düşük politika faizlerinin finansal dengesizlikler meydana getirip getirmediğini incelemektir. Öte yandan bu çalışmada risk alma kanalının etkinliği ile bankaların büyüklük, likidite ve sermaye büyüklükleri arasındaki ilişki de tespit edilmeye çalışılıışır.

Bu çalışmanın literatüre katkıları ise şu şekilde ifade edilebilir. Çalışmada bankaların risk alma ölçütü olarak kullanılan iki değişken yanında banka karakteristikleri, para politikası değişkeni ve makroekonomik faktörlerin dahil edildiği geniş bir veri seti kullanılmıştır. Türkiye için risk alma kanalının varlığının analiz edildiği çalışma sayısı oldukça kısıtlı olmakla birlikte, çalışmaların tümü kullanılan yöntem gereği kısıtlı sayıda değişkenle söz konusu ilişkileri incelemeye çalışmaktadır. Bu çalışma geniş bir veri seti ile Türkiye ekonomisinde risk kanalını analiz ederek literatürü genişletmeyi hedeflemektedir. Çalışmanın ikinci bir katkısı ise, geniş bir veri seti kullanılmasına olanak sağlayan FAVAR modeline eşik fonksiyonu eklenerek oluşturulan 
ve bu çalışma ile literatüre kazandırılan Eşikli Faktörlerle Genişletilmiş Vektör Otoregresyon (Threshold FAVAR ya da T-FAVAR) yönteminin ilk defa kullanılmasıdır ${ }^{1}$. Bu yöntem pek çok avantajı ve katkıyı da beraberinde getirmektedir. Bu katkılardan biri banka karakteristiğinin ve makroekonomik faktörün analize dahil edilmesidir. Bir diğeri, T-FAVAR yönteminin geleneksel Vektör Otoregresyon (VAR) modellerinde yaşanan serbestlik derecesi, değişken seçimi gibi problemleri çözerek pek çok değişkenden elde edilen bilginin analize dahil edilebilmesini sağlamasıdır (Bernanke vd., 2005). Son olarak, T-FAVAR yöntemi sayesinde göz önünde bulundurabilen eşik değeri ile bankaların düşük ve yüksek faiz dönemlerinde risk alma davranışlarındaki farklılıklar analiz edilebilmektedir.

Çalışmanın ilerleyen bölümlerinde sırasıyla literatür özetine, veri ve metodolojinin tanıtılmasına ve ampirik sonuçlara yer verilmiştir.

\section{Literatür Özeti}

Para politikasının risk alma kanalını inceleyen çalışmalar, faizlerin düşük olduğu dönemlerde bankaların risk algılarını değiştirerek riski ve getirisi daha yüksek kredilere yönelip yönelmediklerini incelemektedir. Literatürde yer alan bu çalışmalardan bir kısmı banka karakteristiklerinin risk alma kanalı üzerindeki etkisini gelişmiş ülkeler için incelerken, gelişmekte olan ülkeler için yapılan çalışmalar da bulunmaktadır.

Geliş̧̧ş ülkeler için bu alanda yapılan ilk çalışmalardan biri olan Gambacorta (2009), Avrupa ülkelerinde ve Amerika Birleşik Devletleri'nde (ABD) faaliyet gösteren 600 bankanın verilerini kullanmış ve düşük faizlerin bankaların risk iştahını arttırdığını göstermiştir. Öte yandan bu çalışmada likit ve sermayesi sağlam bankaların daha az risk taşıdıkları sonucuna ulaşılmıştır. 16 gelişmiş ekonomideki 1.100 bankanın incelendiği çalışmada Altunbas vd. (2010) kısa dönemlerin faizlerin düşmesi karşısında bankaların risk iştahının arttığını göstermişler ve risk alma kanalının etkin olduğunu kanıtlayan sonuçlara ulaşmışlardır. Avusturya'da faaliyet gösteren bankaların kredi bazlı verilerinin kullanıldığı çalışmada Gaggl ve Valderrama (2010) Avrupa Merkez Bankası'nın (AMB) oldukça düşük politika faizi uyguladığı 2003-2005 dönemi verilerini kullanmışlar ve düşük faizlerin bankaları risk almaya yönlendirdiğini göstermişlerdir.

Köhler (2012) Avrupa Birliği üyesi 15 ülkeden 2.966 bankanın bilanço verilerini kullandığı çalışmasında daha likit varlıklara sahip olan bankaların daha az riskli buna karşın daha yüksek kredi genişlemesine sahip bankaların ise yüksek riskli olduğuna yönelik kanıtlar elde etmiştir. Kore'de faaliyet gösteren beş bankanın analiz edildiği çalışmada Kim (2014), düşük faiz periyodu uzadıkça bankaların daha fazla risk aldıklarını ortaya koymuştur. Ayrıca, bu çalışmada likit varlık ve güçlü sermaye yapısının banka riskliliğini azalttığı sonucuna ulaşılmıştır. Karapetyan (2016:23) ise Norveç'te risk alma kanalının işlerliğini analiz ettiği çalışmasında 19972010 dönemine ait firma bazlı verileri kullanmıştır. Panel veri regresyon yöntemlerinin kullanıldığı çalışmada parasal genişleme politikalarının uygulandığı dönemlerde bankaların riskli müşterilere verdikleri kredileri arttırdıkları sonucuna ulaşılmıştır. Bunun yanında sermaye oranı yüksek olan bankaların olmayanlara nazaran riskli kredi verme eğilimlerinin daha az olduğu da çalışmadan elde edilen sonuçlar arasındadır.

Colletaz vd. (2018) para politikasının uzun dönemli sistemik risk alma davranışı üzerindeki etkisini Avro bölgesi ülkeleri bazında analiz etmişlerdir. Çalışmada uygulanan uzun dönemli nedensellik analizi sonuçları derin parasal genişleme politikası uygulamalarının sistemik riski arttıııı rol oynayabileceğini ifade etmektedir. Neuenkirch ve Nöckel (2018) Avro bölgesi ülkelerinde para politikası şokuna karşı kredilendirme standartlarının gevşetildiğini ve bu etkinin krizi daha derin yaşayan ülkelerde daha baskın olduğunu göstermişlerdir. Diğer çalışmalardan farklı olarak Avrupa ekonomilerinde geleneksel olmayan para politikalarının risk alma davranışı üzerine etkilerini inceleyen çalışmada Brana vd. (2019) eşikli dinamik panel veri modeli oluşturmuşlardır. Çalışmadan elde edilen ampirik sonuçlar geleneksel olmayan genişletici para politikası uygulamalarının boyutu büyüdükçe risk alma kanalııın daha etkili olduğunu göstermektedir.

ABD bankalarının riskliliğinin fonlama ve kredilendirme riski olarak ayrıştırıldığı çalışmada Angeloni vd. (2015) 1980-2008 dönemini analiz etmiştir. VAR modeli sonuçları para politikasının finansman yapısı ve varlık riskliliğini etkileyerek bankaların risk alma iştahını etkilediğine yönelik kanıtlar sunmuşlardır. ABD'de 30 bankanın analiz edildiği çalışmada Alzuabi vd. (2017) genişletici politikaların sorunlu kredileri arttırdığı ve 
sermaye yapılarının bankaların risk iştahını etkileyen önemli bir faktör olduğunu ortaya koymuşlardır. ABD'de kredi bazlı verileri kullanan Delis vd. (2017) çalışmasında ise para politikası değişimlerinin bankaların risk alma davranışı üzerindeki etkisi incelenirken kredi talebini etkileyen faktörlerin de göz önünde bulundurulması gerektiğini ifade etmişlerdir. Yine Paligorova ve Santos (2017) da bankaların kredi bazlı verilerini kullanarak benzer sonuçlara ulaşmışlardır. Bir diğer çalışmada ise Adrian vd. (2019) VAR modeli sonuçlarına göre parasal daralmanın ABD'de bankaların kar marjlarını daralttığını ve risk iştahlarını artırdığını ifade etmişlerdir.

Gelişmekte olan ülkeler için gerçekleştirilen çalışmalardan Lopez vd. (2011) Kolombiya için gerçekleştirdiği çalışmasında kredi bazlı verileri kullanarak 2000-2008 döneminde iki milyondan daha fazla sayıdaki krediyi analiz etmişlerdir. Çalışmada düşük faizlerin mevcut kredilerin batma olasılığını azaltırken yeni verilen krediler için batma olasılığını arttırdığı sonucuna ulaşmıştır. Ayrıca büyük bankaların risk alma eğiliminin daha az olduğu anlaşıımıştır. Banka bazlı verilerin ve dinamik panel regresyon yöntemlerinin kullandığı çalışmada ise Montes ve Peixoto (2014) Brezilya bankalarını 2001-2011 aylık verilerini kullanarak analiz etmişlerdir. Çalışmanın sonuçlarına göre genişletici para ve zorunlu rezerv politikalarııı uygulandığı dönemlerde bankaların kredi karşılıklarını azalttıklarını ve daha fazla risk aldıklarını göstermektedir. Brezilya bankacılık sisteminin analiz edildiği bir diğer çalışmada ise De Moraes vd. (2016) 2001-2013 dönemi aylık verilerini kullanarak dinamik panel veri regresyon modeli yardımıyla benzer sonuçlara ulaşmışlardır.

Huey ve Li (2016) para politikasının bankaların kredilendirme standartları üzerindeki etkilerini Malezya için 2007-2015 dönemi aylık verilerini kullanarak incelemişlerdir. Panel veri regresyon modelinden elde edilen sonuçlar parasal genişleme dönemlerinde kredilendirme standartlarının kredi türlerine göre farklılık gösterdiğini ve böylelikle risk alma kanalının kısmen etkili olduğunu ortaya koymaktadır. Gelişmekte olan 29 ülkeden 1000 bankanın verilerinin kullanıldığı çalışmada Chen vd. (2017) parasal genişlemenin bankaları daha fazla risk almaya yönelttiği sonucuna ulaşmışlardır. Ayrıca para politikasının daha şeffaf ve bankacılık sektörünün daha yoğun olduğu ülkelerde risk alma kanalının daha etkin olduğuna yönelik kanıtlar elde etmiştir. Hindistan için 86 bankanın analiz edildiği çalışmada Sarkar ve Sensarma (2019) genişletici para politikasının desteklediği risk alma kanalının yabancı bankalarda ve yeni özel bankalarda daha baskın olduğu sonucuna ulaşıımıştır. Çin için yapılan çalışmada Kang vd. (2019) para politikasının risk alma kanalı üzerindeki etkisinin değerleme etkisi ve getiri arama etkisi aracılığıyla çalıştığını göstermişlerdir.

Gelişmiş ve gelişmekte olan ülkelerden 29 büyük global bankanın FAVAR modeli kullanılarak analiz edildiği çalışmada Faia ve Karau (2019) risk alma kanalının yalnızca ülke bazlı politikalardan değil aynı zamanda FED'in politika kararlarından da etkilendiğine yönelik kanıtlar elde etmişlerdir. Zhou ve Tewari (2019) Gelişmekte olan ülkeler gölge bankacılığın ve para politikasının risk alma kanalını incelemişlerdir. Çalışmada eşbütünleşme analizinden elde edilen sonuçların para politikası şoku sonucunda azalan bankacılık riskinin gölge bankacılık faaliyetlerini arttırdığı tespit edilmiştir.

Türkiye'de risk alma kanalııın incelendiği çalışmalar oldukça sınırlı sayıdadır. Bu çalışmalarda dinamik panel veri regresyon yöntemleri kullanılmıştır. Ayaydın ve Karakaya (2014) banka bazlı bilanço verilerine dayanarak 2003-2011 dönemini kapsayan çalışmalarında sermaye düzeyi ile risk göstergeleri arasında risk değişkenlerine göre değişen sonuçlar elde etmişlerdir. Diğer bir çalışmada, Adanur Aklan vd. (2014) 20032012 dönemi çeyreklik verilerini kullanarak kısa vadeli faiz oranlarının bir gösterge seviyesinin altında olduğunda bankaların risk alma oranlarını artırdığı sonucuna ulaşmışlardır. Ancak kısa vadeli faizlerin düşük olduğu dönemlerde büyük veya sermayesi güçlü bankaların riskli kredilere daha az yöneldikleri tespit edilmiştir. Benzer şekilde, Özşuca ve Akbostancı (2016) 2002-2016 dönemi verilerini kullanarak risk alma kanalının etkin olduğunu gösterirken, daha likit, büyük ve sermayesi güçlü bankaların para politikası değişikliklerine karşı risk alma eğilimlerinin daha az olduğu sonucuna ulaşmışlardır.

Literatürde yer alan çalışmaların büyük bölümünün panel veri regresyon modellerine dayandığı, bunun yanında çeşitli VAR modelleri ve probit modellerini kullanan çalışmaların da olduğu görülmektedir. Literatürde özellikle gelişmiş ülkeler için gerçekleştirilen çalışmaların sayıca fazla olduğu görülmektedir. Yine bu ülkelerde parasal genişleme politikaları kapsamlı ve etkin uygulandığından risk alma kanalının daha etkin çalıştığı ifade edilebilir. Bu çalışmamız gelişmekte olan ülke literatürünü genişletme amacını taşımakla birlikte ampirik açıdan da daha önce değinilen avantajları barındırmaktadır. 


\section{Veri Seti ve Değişkenler}

\subsection{Veri Seti}

Bu çalışmada Türkiye'de risk alma kanalının etkinliği en az on şube ile faaliyet gösteren 19 mevduat bankasının verileri kullanılarak incelenmiştir. Çalışmada kullanılan bankaların listesine eklerde yer alan Tablo A.1'de yer verilmiştir. Çalışmada çeyreklik veriler kullanılmış olup, çalışma 2003:Q1-2019:Q2 dönemini kapsamaktadır. Veri seti banka bilanço verileri, para politikası değişkeni ve makroekonomik değişkenlerden oluşmaktadır. Çalışmada kullanılan değişkenlerin isimleri, kısaltmaları ve kaynakları gibi veri setine ilişkin detaylara Tablo 1'de değinilmiştir.

Tablo 1. Değişken Bilgileri

\begin{tabular}{|c|c|c|c|c|c|}
\hline $\begin{array}{l}\text { Değişken } \\
\text { Grubu }\end{array}$ & $\begin{array}{l}\text { Değişken } \\
\text { Kodu }\end{array}$ & Değişken Tanımı & Kısaltma & Birim & Kaynak \\
\hline \multirow{2}{*}{ 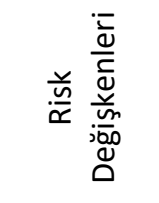 } & \multirow[b]{2}{*}{ R1-R38 } & Z-Endeksi & Z-IND & Oran & TBB \\
\hline & & $\begin{array}{l}\text { Kredi Karşlıkları/Toplam } \\
\text { Varlıklar }\end{array}$ & LLPTA & Oran & TBB \\
\hline 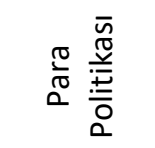 & R134 & $\begin{array}{l}\text { Bankalararası Para Piyasası Faiz } \\
\text { Oranı }\end{array}$ & MP & $\%$ & $\begin{array}{c}\text { Thomson } \\
\text { Reuters }\end{array}$ \\
\hline \multirow{5}{*}{ 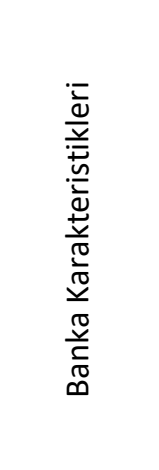 } & R39-R57 & Likit Varlıklar/Toplam Varlıklar & LIQR & Oran & TBB \\
\hline & R58-R76 & Sermaye/Toplam Varlıklar & ETA & Oran & TBB \\
\hline & R77-R95 & $\begin{array}{l}\text { Dönem Net Karı/Toplam } \\
\text { Varlıklar }\end{array}$ & ROA & Oran & TBB \\
\hline & R96-R114 & Toplam Varlıklar & TA & Oran & TBB \\
\hline & R115-R133 & Fazladan Kredi Genişlemesi & CEXP & Oran & TBB \\
\hline \multirow{4}{*}{ 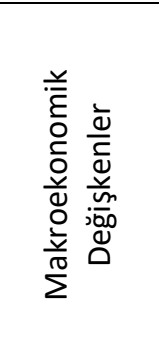 } & R135 & Tüketici Fiyat Endeksi & CPI & Endeks & $\begin{array}{c}\text { Thomson } \\
\text { Reuters }\end{array}$ \\
\hline & R136 & Hazine Bonosu Faizi (9 Aylık) & SHORT & $\%$ & $\begin{array}{c}\text { Thomson } \\
\text { Reuters }\end{array}$ \\
\hline & R137 & Reel Efektif Döviz Kuru & REER & Endeks & $\begin{array}{c}\text { Thomson } \\
\text { Reuters }\end{array}$ \\
\hline & R138 & Gayrisafi Yurtiçi Hasıla & GDP & $\operatorname{Bin} \mathrm{TL}$ & $\begin{array}{c}\text { Thomson } \\
\text { Reuters }\end{array}$ \\
\hline
\end{tabular}

Not: Türkiye Bankalar Birliği (TBB) bankaların halka açık bilanço verilerini sunmaktadır.

\subsection{Değişkenler}

Risk alma kanalının etkinliğinin analiz edildiği bu çalışmada banka riski göstergesi olarak iki değişken kullanılmıştır. Bunlardan ilki literatürde sıklıkla kullanılan Z-endeksidir. Z-endeksi şu formülle hesaplanmaktadır. 
$Z_{i}=\frac{R O A_{i, t}+E T A_{i, t}}{\sigma_{R O A_{i, t}}}$

Bu formülde $R O A_{i}$ ilgili bankanın ilgili çeyrekteki aktif karlıık oranını, $E T A_{i}$ bankanın sermaye oranını göstermekle birlikte $\sigma_{R O A_{i}}$ ise ilgili bankanın varlık karlıığının standart sapmasını göstermektedir. $R O A_{i}$ değişkeni bankanın net karının toplam varlıklara oranını, $E T A_{i}$ değişkeni ise bankanın toplam sermayesinin toplam varlıklara oranını ifade etmektedir. Bir bankanın temerrüde düşmesi için varlık karlılığı değişkeninin kaç standart sapma düşmesi gerektiğini gösteren Z-endeksi literatürde pek çok çalışmada risk ölçütü olarak kullanılmıştır (örneğin; Özşuca ve Akbostancı, 2016; Köhler, 2012; Chen vd., 2017).

Risk göstergesi olarak kullanılan ikinci değişken ise kredi karşılıklarının toplam kredilere oranı (LLPTA) değişkenidir. Bu oran bankaların gelecekteki kayıpları amacıyla ayırdıkları nakit dışı bir gider olarak kredi riskinin bir ölçütü olarak kullanılmaktadır (De Santis vd., 2013: 438). LLPTA oranının yükselmesi riskin arttığını ifade etmektedir.

Çalışmada para politikası değişkeni olarak bankalar arası para piyasası gecelik faiz oranı (MP) kullanılmıştır. Bu değişken, bankaların gerçek maliyetini göstermektedir (Altunbas vd., 2010: 13). Literatürde para politikasının tanımlanması amacıyla pek çok çalışmada bankalar arası para piyasası değişkeni kullanılmıştır (örneğin; Lopez vd., 2011: 225; Özşuca ve Akbostancı, 2016: 593).

Bu çalışmada kullanılan bir diğer değişken grubu ise banka karakteristiklerini içermektedir. Bu değişkenler para politikası değişikliklerinin bankaların büyüklük, likidite, sermaye düzeyi ve karlılı̆ı üzerindeki etkilerini ortaya koymak amacıyla modele dahil edilmiştir. Zira para politikası değişikliklerine karşı bankaların tepkilerinin banka karakteristikleri nedeniyle heterojen olduğu ifade edilmektedir (Kashyap ve Stein, 1995: 151). Bu amaçla çalışmada banka büyüklüğü Toplam Varlıklar (TA) değişkeniyle, likidite durumu Likidite Oranı (LIQR) değişkeniyle, sermaye güçlülüğü Sermaye Oranı (ETA) değişkeniyle ve son olarak banka karlılığı ise Karlııı Oranı (ROA) değişkeniyle gösterilmiştir. Ayrıca, analize dahil edilen bir diğer banka karakteristiği ise Fazladan Kredi Genişlemesi (CEXP) değişkenidir. Bu değişken politika faizi ile banka riski arasındaki ilişki incelenirken fazladan kredi artışının banka riski üzerindeki etkisini bertaraf etmek amacıyla analize dahil edilmiştir (Altunbas vd., 2010: 20; Özşuca ve Akbostancı, 2016: 593).

Çalışmada yer verilen son değişken grubu ise makroekonomik faktörleri içermektedir. Çalışmada kullanılan makroekonomik faktörler Tüketici Fiyat Endeksi (CPI), kısa dönemli faiz oranları değişkeni olarak Hazine Bonosu Faiz Oranı (SHORT), Reel Efektif Döviz Kuru (REER) ve hem reel ekonomik aktiviteyi hem de kredi talebini kontrol etmek amacıyla da Gayrisafi Yurtiçi Hasıla (GDP) değişkenleridir. Çalışmada kullanılan değişkenlere ilişkin tanımlayıcı istatistiklere Tablo 2 'de yer verilmiştir. ${ }^{2}$

Tablo 2. Tanımlayııı İstatistikler

\begin{tabular}{|c|c|c|c|c|c|c|c|}
\hline $\begin{array}{l}\text { Değişken } \\
\text { Kodu }\end{array}$ & Değişken Tanımı & Kısaltma & Minimum & Maksimum & Ortalama & Medyan & $\begin{array}{l}\text { Standart } \\
\text { Sapma }\end{array}$ \\
\hline R1-R19 & Z-Endeksi & Z-IND & $-0,0394$ & 0,0351 & 0,0004 & 0,0001 & 0,0041 \\
\hline R20-R38 & $\begin{array}{l}\text { Kredi } \\
\text { Karşılıkları/Toplam } \\
\text { Varlıklar }\end{array}$ & LLPTA & $-2,4400$ & 62,8888 & 17,4099 & 16,5517 & 9,3992 \\
\hline R39-R57 & $\begin{array}{l}\text { Likit Varlıklar/Toplam } \\
\text { Varlıklar }\end{array}$ & LIQR & $-0,2940$ & 0,3765 & $-0,0011$ & $-0,0024$ & 0,0450 \\
\hline R58-R76 & $\begin{array}{l}\text { Sermaye/Toplam } \\
\text { Varlıklar }\end{array}$ & ETA & $-0,3226$ & 0,4719 & $-0,0007$ & $-0,0004$ & 0,0224 \\
\hline R77-R95 & $\begin{array}{l}\text { Dönem Net } \\
\text { Karı/Toplam Varlıklar }\end{array}$ & ROA & $-0,1034$ & 0,1416 & $0, .0001$ & 0,0021 & 0,0103 \\
\hline
\end{tabular}


Tablo 2. Tanımlayıcı İstatistikler (Devamı)

\begin{tabular}{|c|c|c|c|c|c|c|c|}
\hline R96-R114 & Toplam Varlıklar & TA & $-0,2573$ & 0,5525 & 0,0475 & 0,0440 & 0,0762 \\
\hline R115-R133 & $\begin{array}{l}\text { Fazladan Kredi } \\
\text { Genişlemesi }\end{array}$ & CEXP & $-1,3112$ & 1,6887 & 0,0003 & $-0,0002$ & 0,1334 \\
\hline R134 & $\begin{array}{l}\text { Bankalararası Para } \\
\text { Piyasası Faiz Oranı }\end{array}$ & MP & $-0,3678$ & 6,6145 & 2,3186 & 2,2657 & 1,6033 \\
\hline R135 & Tüketici Fiyat Endeksi & $\mathrm{CPI}$ & 54,7000 & 4,4600 & 14,5549 & 11,6020 & 9,7473 \\
\hline R136 & $\begin{array}{l}\text { Hazine Bonosu Faizi ( } 9 \\
\text { Aylık) }\end{array}$ & SHORT & 8,5237 & $-11,2533$ & $-0,2220$ & 0,7478 & 4,9973 \\
\hline R137 & Reel Efektif Döviz Kuru & REER & 0,9571 & $-1,0444$ & 0,1878 & 0,3839 & 0,5475 \\
\hline R138 & Gayrisafi Yurtiçi Hasıla & GDP & 0,5800 & $-1,6500$ & 0,0174 & 0,0200 & 0,3745 \\
\hline
\end{tabular}

\section{Yöntem}

Bu çalışmada para politikasının risk alma kanalını incelemek amacıyla zengin bir veri setinden yararlanma imkânı sunan FAVAR modeli kullanılmaktadır. FAVAR modeli Bernanke vd. (2005) tarafından para politikasının etkilerini incelemek amacıyla geliştirilmiştir. Bu yaklaşım, çok sayıda makro iktisadi değişkenden ilk aşamada temel bileşenler analizi ile ortak faktörler türetilmesini ve ikinci aşamada faktörlerin de yer aldığı bir VAR analizini kapsamaktadır. Standart VAR modelleri, aşırı parametreleşme durumunda karşı karşıya kaldığı serbestlik derecesi vb. problemler nedeniyle birkaç değişkenle sınırlı bir analiz önermektedir. FAVAR yaklaşımının temel avantajlarından biri bu sorunun üstesinden gelerek, incelenen ilişki içerisinde etkili olabilecek çok sayıda değişkeni modele dahil etmeye izin vermesidir. Bu sayede, model dışında bırakılan ancak teorik olarak para politikasının aktarım mekanizmalarında etkisi olabilecek tüm ilişkiler içerilmektedir.

Eşik VAR modelinin tahmin edilebilmesi için öncelikle faktörlerin türetilmesi gerekmektedir. FAVAR modelinin tahmini için kullanılan geniş veri setinde yer alan her bir değişkenin belirli ağırlıklarla temsil edildiği faktör serilerinin elde edilmesi için aşă̆ıdaki eşitlik kullanılmaktadır:

$$
X_{t}=\wedge^{f} F_{t}+\wedge^{y} Y_{t}+u_{t}
$$

(2) nolu eşitlikte $\wedge^{f}$ her değişken için faktör yüklerini ifade etmektedir. Bir başka deyişle her bir faktörün oluşturulmasında her bir değişkenin katkısını belirtmektedir. $\wedge^{y}$ ise her bir değişkenin katsayısını temsil etmektedir. $u_{t}$ ise sıfır ortalamaya sahip ve ilişkisiz ya da zayıf ilişkili hata terimidir. Bu eşitlik temel bileşenler analizi yöntemiyle tahmin edilerek faktör serileri elde edilmektedir. Bu yaklaşımda ilk aşamada ortak faktörler $X_{t}$ serilerini kullanarak toplanmaktadır. Ardından veri setinde yer alan tüm değişkenler, modelde yer alan şoklara verdikleri tepkilerin hızına bağlı olarak yavaş $\left(\mathrm{F}_{t}{ }^{\mathrm{S}}\right)$ ve hızı ${ }\left(\mathrm{F}_{\mathrm{t}}{ }^{\mathrm{F}}\right)$ değişkenler olarak kategorize edilmektedir. Modelde yer alan gözlemlenebilen değişkenlerdeki şoklara, şokun meydana geldiği dönemde tepki veren değişkenler, hızlı değişkenler kategorisinde yer almaktadır. Yavaş değişkenler ise, gözlemlenebilen değişkenlerdeki değişimlere en az bir dönem gecikmeli olarak tepki vermektedir. Üçüncü aşamada ise yavaş ve hızlı değişkenler kullanılarak aşağıdaki eşitlik tahmin edilmektedir ve faktör serileri türetilmektedir:

$$
X_{t}=b^{f} \hat{F}_{t}^{s}+b^{y} \hat{Y}_{t}+e_{t}
$$

Temel bileşenler analizi vasıtasıyla faktör serilerin türetilmesinden sonra yöntemin son aşaması olarak VAR tahmini gerçekleştirilmektedir. Çalışma aynı zamanda, incelenen örneklem içerisinde faiz karakteristiğine bağlı olarak iki rejim belirlemek ve bu iki rejimde risk kanalının etkinliğini ve etkilerini çalışmak amacıyla, eşik FAVAR modelini geliştirmektedir.

Çalışmada kullanılan eşikli FAVAR modeli doğrudan gözlemlenebilen değişkenler ile gözlemlenemeyen faktörlerin yer aldığı bir eşik VAR modeline dayanmaktadır: 


$$
\left[\begin{array}{l}
F_{t} \\
Y_{t}
\end{array}\right]=\left[\begin{array}{l}
\Gamma_{1, t} \\
\Gamma_{2, t}
\end{array}\right]\left[\begin{array}{l}
F_{t-p} \\
Y_{t-p}
\end{array}\right]\left(1-I_{t}\right)\left[Z_{t-d}<z^{*}\right]+\left[\begin{array}{l}
\Gamma_{3, t} \\
\Gamma_{4, t}
\end{array}\right]\left[\begin{array}{l}
F_{t-p} \\
Y_{t-p}
\end{array}\right] I_{t}\left[Z_{t-d} \geq z^{*}\right]+\left[\begin{array}{l}
u_{1, t} \\
u_{2, t}
\end{array}\right]
$$

(4) numaralı eşitlik eşik VAR modeli gösteriminin gözlemlenebilen ve gözlemlenemeyen değişkenlerle genişletilmiş bir versiyonudur. $Y_{t}$ doğrudan gözlemlenebilen değişkeni ifade ederken, $F_{t}$ ise gözlemlenemeyen ve birinci aşamada temel bileşen analizinden elde edilen faktörleri ifade etmektedir. $\Gamma_{i, t}$ VAR modelinin polinominal gecikme katsayı matrisini ifade ederken, $\mathrm{u}_{\mathrm{i}, \mathrm{t}}$ sıfır ortalamalı hata terimidir. $\mathrm{z}_{\mathrm{t}-\mathrm{d}}$ terimi sistemdeki rejimleri tanımlayan bir eşik değişkenidir ve d parametresi eşiklerin belirlenmesinde dikkate alınan gecikmeyi ifade eder. Buna göre, $z_{t-d}, d$ dönem önceki $z$ değeridir ve eğer bu değer eşik değer olan $z^{* \prime}$ dan yüksek ise I değişkeni bir değerini almaktadır. Aksi durumda I sıfır değerini alarak bir diğer rejimi tanımlamaktadır.

VAR tahminlerinin ardından gözlemlenebilen değişkenlerde meydana gelen bir şokun etkilerinin ölçülmesi amacıyla etki tepki fonksiyonlarından yararlanılmaktadır. Ancak eşik VAR yönteminde standart etki tepki fonksiyonlarının kullanılamaması nedeniyle, Koop vd. (1996) tarafından geliştirilen genelleştirilmiş etki tepki fonksiyonları kullanılmaktadır. Buna göre, genelleştirilmiş etki tepki fonksiyonları şokun meydana geldiği dönemden sonra rejimin değişmesine izin vermekle birlikte basitçe iki koşullu beklentinin farkı olarak hesaplanmaktadır:

$$
\begin{aligned}
& G E T=E\left[Y_{t+m} \mid \epsilon_{t}, \epsilon_{t+1}=0, \ldots, \in_{t+m}=0, \Omega_{t-1}\right]-E\left[Y_{t+m} \mid \epsilon_{t}=0, \in_{t+1}=0, \ldots, \in_{t+m}=\right. \\
& \left.0, \Omega_{t-1}\right]
\end{aligned}
$$

Bu eşitlikte $\epsilon_{t}$ şokun büyüklüğünü ve $m$ genelleştirilmiş etki tepki fonksiyonlarının tahmin dönemini ifade ederken, $\Omega_{t-1}$ bilgi setidir.

\section{Bulgular}

Çalışmada, Türkiye'de para politikasının risk alma kanalı, banka bilançoları ve makroekonomik değişkenlerden oluşan geniş bir set kullanılarak analiz edilmiştir. Bu geniş veri seti ile temelde farklı para politikası koşullarında bankaların risk alma davranışlarının değişip değişmediği incelenmiştir. Hem risk alma kanalının etkinliğinin saptanması hem de makroekonomik etkilerinin belirlenmesi amacıyla özgün bir eşik FAVAR modeli kullanılmıştır. FAVAR modeli tahmin aşamalarına geçmeden önce değişkenlerin durağanlıkları incelenmiştir. FAVAR modelinde kullanılan değişkenlerin durağan olması gerektiğinden bu çalışmada serilere Augmented Dickey-Fuller (ADF) ve Phillips Perron (PP) birim kök testleri uygulanmıştır. Değişkenlerden seviyede durağan olmayanların birinci farkları alınarak durağan hale getirilmiştir. ${ }^{3}$

Eşik FAVAR modeli tahmininin ilk ampirik aşamasında, oluşturulan veri setini optimal olarak temsil eden faktör sayısının belirlenmesi gerekmektedir. Temel bileşenler analizinde faktör sayısının belirlenmesi konusunda literatürde iki yaklaşım olduğu savunulabilir. Bunlardan ilki ve bu çalışmada kullanılan yaklaşım, temel bileşenler analizinin sunmuş olduğu öz değerlerden yararlanmaktır. Buna göre, her faktör sayısında hesaplanan öz değerler ve tüm değişkenlerin varyansını açıklama gücü kriter olarak ele alınmaktadır. Bu değerler belirli bir temsiliyet gücüne ulaştığında ve yeni bir faktör eklenmesi bu parametrelerde önemli sayılabilecek bir artışa yol açmadığında optimal faktör sayısına ulaşıldığı düşünülmektedir. Bununla birlikte, Bai ve Ng (2008) tarafından geliştirilen test literatürde tamamlayıcı bir yöntem olarak değerlendirilmektedir.

Tablo 3 temel bileşen analizi sonuçlarını içermektedir. Tabloda farklı faktör sayılarında öz değerler, öz değerlerdeki değişim ve faktörlerin toplam varyansın yüzde kaçını açıklayabildiği bilgileri yer almaktadır. Buna göre, öncelikle tüm faktör sayılarında öz değerlerin kendisi birden yüksek olarak elde edilmiş olsa da öz değerler arasındaki farkın dördüncü faktörden sonra birin altına düştüğü görülmektedir. Bununla birlikte, ilk dört faktörün toplam varyansın \%40'ını açıklama kabiliyetine sahip olduğu anlaşılmaktadır. Bu ampirik koşullar altında veri setinin dört faktör ile optimal biçimde temsil edileceği sonucuna ulaşılmaktadır. Bunun yanı sıra, Bai ve $\mathrm{Ng}$ (2008) tarafından geliştirilen ve panel veri setlerinde faktör sayısını belirlemeye yönelik prosedür benzer sonuçlar rapor etmektedir. 
U. Akkoc - O. Ozgur

Tablo 3. Temel Bileşenler Analizine Göre Öz Değerler

\begin{tabular}{cccccc}
\hline Faktör Sayısı & Öz Değer & Fark & Oran & $\begin{array}{c}\text { Kümülatif Öz } \\
\text { Değer }\end{array}$ & Kümülatif Oran \\
\hline 1 & 17,045 & 2,071 & 0,144 & 17,045 & 0,144 \\
2 & 14,973 & 5,566 & 0,126 & 32,019 & 0,271 \\
3 & 9,407 & 3,082 & 0,079 & 41,427 & 0,351 \\
4 & 6,325 & 1,183 & 0,053 & 47,753 & 0,404 \\
5 & 5,142 & 0,689 & 0,043 & 52,895 & 0,448 \\
6 & 4,452 & 0,376 & 0,037 & 57,348 & 0,486 \\
7 & 4,076 & 0,379 & 0,034 & 61,425 & 0,520 \\
8 & 3,697 & 0,379 & 0,031 & 65,122 & 0,551 \\
9 & 3,318 & 0,110 & 0,028 & 68,440 & 0,580 \\
10 & 3,207 & 0,092 & 0,027 & 71,647 & 0,607 \\
\hline
\end{tabular}

Faktör sayısının belirlenmesinin ardından, tüm veri setini temsil etme gücüne sahip olan bu faktörlerin kavramsallaştırılması gerekmektedir. Bir başka deyişle, her bir faktörün veri setinde doğrudan gözlemlenemeyen hangi iktisadi olgu ya da olguları temsil ettiği belirlenmelidir. Bunun gerçekleştirilmesi için değişkenlerin faktör yüklerinden yararlanılmaktadır. Faktör serileri gözlemlenebilen değişkenlerin belirli oranlarındaki kombinasyonlarından oluşmaktadır. Dolayısıyla, faktör yükleri, tüm değişkenler için hangi faktörde ne oranda içerildiğinin bilgisini sunmaktadır.

Çalışmanın tutarlılık doğrulamasının sağlanması amacıyla iki risk ölçütü dikkate alınmıştır: Bunlar Zendeksi ve LLPTA değişkenleridir. Dolayısıyla içsellik sorunu ile karşılaşmamak için banka karakteristikleri ve makro ekonomik faktörlerle birlikte her bir risk değişkeninin eklendiği iki ayrı veri seti oluşturulmuştur. iki veri setinde yer alan tüm değişkenler arasında yalnızca risk değişkenleri farklılık göstermektedir. Bu nedenle Tablo 4'te her bir veri setine ait dördüncü faktör sonuçları birlikte sunulmaktadır.

Tablo 4. Faktör Yükleri

\begin{tabular}{|c|c|c|c|c|c|c|c|c|c|}
\hline \multirow{2}{*}{$\begin{array}{l}\text { Faktör } 1 \\
\text { Değişken }\end{array}$} & \multirow[b]{2}{*}{$\begin{array}{l}\text { Faktör } \\
\text { Yükü }\end{array}$} & \multirow{2}{*}{$\begin{array}{l}\text { Faktör } 2 \\
\text { Değişken }\end{array}$} & \multirow[b]{2}{*}{$\begin{array}{l}\text { Faktör } \\
\text { Yükü }\end{array}$} & \multirow{2}{*}{$\begin{array}{l}\text { Faktör } 3 \\
\text { Değişken }\end{array}$} & \multirow[b]{2}{*}{$\begin{array}{l}\text { Faktör } \\
\text { Yükü }\end{array}$} & \multicolumn{2}{|c|}{ Faktör 4 (LLPTA) } & \multicolumn{2}{|c|}{$\begin{array}{l}\text { Faktör } 4 \\
\text { (Z-endeksi) }\end{array}$} \\
\hline & & & & & & Değişken & $\begin{array}{l}\text { Faktör } \\
\text { Yükü }\end{array}$ & Değişken & $\begin{array}{l}\text { Faktör } \\
\text { Yükü }\end{array}$ \\
\hline R77 & 0,568 & R63 & 0,427 & R57 & 0,741 & R5 & 0,185 & R135 & 0,632 \\
\hline R83 & 0,567 & R79 & 0,410 & R39 & 0,652 & $\mathrm{R} 2$ & 0,145 & $\mathrm{R} 27$ & 0,581 \\
\hline R95 & 0,560 & R58 & 0,386 & R48 & 0,630 & R91 & 0,110 & R30 & 0,464 \\
\hline R89 & 0,472 & R80 & 0,372 & R44 & 0,566 & $\mathrm{R} 117$ & 0,108 & $\mathrm{R} 20$ & 0,428 \\
\hline R93 & 0,472 & R82 & 0,372 & R50 & 0,508 & $\mathrm{R} 18$ & 0,099 & $\mathrm{R} 24$ & 0,421 \\
\hline R88 & 0,465 & R88 & 0,370 & R55 & 0,480 & R4 & 0,097 & R35 & 0,372 \\
\hline R90 & 0,465 & R95 & 0,363 & R49 & 0,451 & R13 & 0,095 & $\mathrm{R} 22$ & 0,309 \\
\hline R87 & 0,459 & R87 & 0,357 & R53 & 0,417 & R14 & 0,094 & $\mathrm{R} 26$ & 0,300 \\
\hline R80 & 0,440 & R93 & 0,350 & R45 & 0,409 & R6 & 0,093 & R34 & 0,244 \\
\hline R137 & 0,437 & R77 & 0,346 & R51 & 0,392 & R72 & 0,087 & R25 & 0,169 \\
\hline
\end{tabular}

Not: Faktör 4 (LLPTA) banka karakteristikleri ve makro ekonomik değişkenler ile LLPTA cinsinden risk ölçütlerinin yer aldığı veri setine uygulanan temel bileşen analizine göre dördüncü faktör sonuçlarını göstermektedir. Faktör 4 (z endeksi) benzer şekilde, $z$ endeksi ve diğer değişkenlerle oluşturulan veri setine ilişkin dördüncü faktör sonuçlarını yansıtmaktadır.

Tablo 4'te yer alan sonuçlar her bir faktör için faktör yükünün en yüksek olduğu ilk on değişkeni ve ilgili faktörün değişkenleri açıklama yüzdesini içermektedir. Bu sonuçlar incelendiğinde, ilk faktörü oluşturan değişkenlerin büyük ölçüde banka karlılığı ile ilişkili olduğu görülmektedir. Dolayısıyla ilk faktörü "karlılık" olarak nitelendirmek mümkündür. Benzer biçimde ikinci faktör için en yüksek faktör yüküne sahip olan değişkenler içerisinde iki grup değişken olduğu anlaşılmaktadır: Karlılık ve sermaye oranı değişkenleri. Dolayısıyla ikinci faktör "sermaye" faktörü olarak tanımlanmıştır. Benzer çıkarımla üçüncü ve dördüncü 
faktörlerin sırasıyla "likidite" ve "risk" faktörü olduğu görülmektedir. Risk faktörü çalışmanın odağını oluşturan risk kanalının incelenmesine ilişkin, para politikası değişikliklerine vereceği tepkilerin izleneceği temel faktördür. Bu dört faktörün veri setinde yer alan değişkenleri açıklama gücü tek tek regresyonlarla elde edilmiştir. Buna göre, ortalamada faktörlerin değişkenleri açıklama gücü \%35'tir.

Temel bileşenler analizi ile oluşturulan dört faktör serisi ve doğrudan gözlemlenebilen faiz değişkeni ile eşik VAR modeli tahmin edilmiştir. Faiz değişkeni olarak gecelik bankalar arası piyasada oluşan faiz oranı kullanılmıştır ve para politikasını yansıttığı düşünülmektedir. Bu aşamada gerçekleştirilen eşik VAR tahmini için öncelikle optimal gecikme uzunluğunun belirlenmesi gerekmektedir. Beş değişkenli eşik VAR modeli için, Schwarz bilgi kriteri optimal gecikme uzunluğunun birinci veri setinde bir ve ikinci veri setinde iki olduğunu önermektedir. Çeyreklik verilerden oluşturulan veri seti kullanıldığı göz önüne alındığında bir ve iki çeyreklik gecikmelerin teorik beklentilerle de uyumlu olduğu değerlendirilmiştir.

Eşik VAR tahmininde kullanılan bir diğer parametre ise eşik değişkeni ve eşik değeridir. Eşik VAR modelleri, seçilen eşik değişkenin belirli bir eşik değerin altında ve üstünde olduğu iki ayrı rejimde VAR modelini tahmin ederek genelleştirilmiş etki tepki fonksiyonlarını türetmektedir. Çalışmanın odak noktasının para politikasında risk kanalının analiz edilmesi olduğu düşünüldüğünde eşik değişken para piyasası koşullarını yansıtması amacıyla faiz değişkeni olarak belirlenmiştir. Öte yandan, faiz değişkeninin eşik değeri olarak incelenen dönemdeki faiz dağılımının ilk çeyreklik diliminin sınırını oluşturan \%6,6 değeri seçilmiştir ${ }^{4}$. Bu sayede karşılaştırmalı olarak düşük faiz rejimi olarak adlandırılabilecek birinci rejim faiz oranının düşük ya da makul seviyede olduğu bir rejim olarak tanımlanabilir ${ }^{5}$. Aksine faiz oranının \%6,6'nın üzerinde gerçekleştiği dönemler yüksek faiz rejimini oluşturmaktadır. Oluşturulan T-FAVAR modeli OLS tahmin edicisi kullanılarak tahmin edilmiştir.

Şekil 1'de düşük ve yüksek faiz dönemlerinin grafiksel gösterimine yer verilmiştir.

Şekil 1. Rejim Dönemleri ve Faiz Oranı

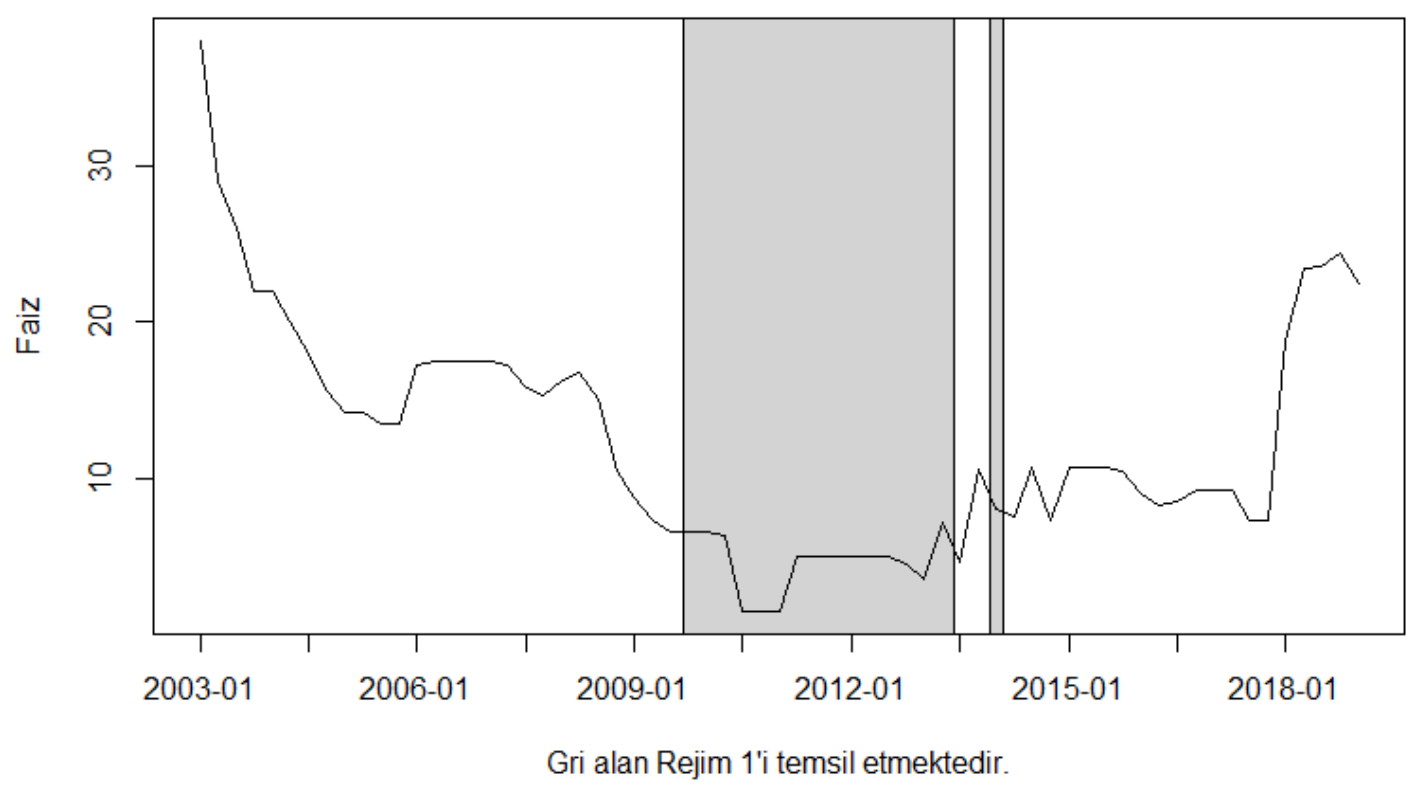

Şekil 2, risk faktörü olarak nitelenen dördüncü faktörün bir standart sapmalık negatif faiz şokuna (genişletici para politikası şoku) verdiği kümülatif tepkileri her iki rejimde sunmaktadır. Bir başka deyişle, bankalar arası piyasada oluşan gecelik faizde meydana gelecek bir puanlık düşüşün, bankaların risk alma davranışlarını temsil eden risk faktörleri üzerindeki etkileri hem düşük hem yüksek faiz rejimlerinde yirmi dönem boyunca izlenebilmektedir. Şekilde yer alan güven aralıkları bootstrap yöntemiyle elde edilmiştir.

Çalışmanın temelini oluşturan risk faktörlerinin etki tepki grafikleri incelendiğinde, her iki rejimde de faiz düşüşü Z-endeksinde de bir düşüşe neden olmaktadır. Ancak Z-endeksi, hesaplama yöntemi gereği olarak 
riskin bir ters ölçütüdür. Bir başka deyişle, z endeksinin artışı riskin azalması anlamını taşımaktadır. Dolayısıyla Z-endeksinde meydana gelen düşüş risk artışı olarak yorumlanmalıdır. Üstelik faiz artışı karşısında riskin davranışı kısa dönemde düşme uzun dönemde ise artma eğilimindedir. Bu durum, literatürde risk kanalına ilişkin teorik beklentiler ile son derece uyumludur (Özşuca ve Akbostancı, 2016; Alzuabi vd., 2017). Buna göre, faiz düşüşü biçimindeki genişletici para politikası sonrasında risk iştahı artmaktadır. Z-endeksinin tanımından hareketle düşük faiz ortamında bankalar düşen kar marjlarını farklı varlıklardan elde ettikleri yüksek getirilerle telafi edemediğinden daha riskli varlıklara yönelmektedirler (Brana vd., 2019). Bu durumda faiz düşüşünün nihai etkisi uzun dönemde risk artışı olarak izlenmektedir. Nihayetinde Z-endeksine ait etki tepki grafikleri, faiz rejiminden bağımsız olarak faiz düşüşünün Z-endeksinde önce artışa sonra düşüşe neden olduğunu ve risk kanalının etkin şekilde çalıştığını ima etmektedir. Bu çalışmamızda Z-endeksi kullanılarak elde edilen sonuçlar Türkiye için gerçekleştirilen Özşuca ve Akbostancı (2016: 603) ile tutarlılık göstermektedir.

Şekil 2. Risk Faktörünün Kümülatif Etki Tepki Sonuçları

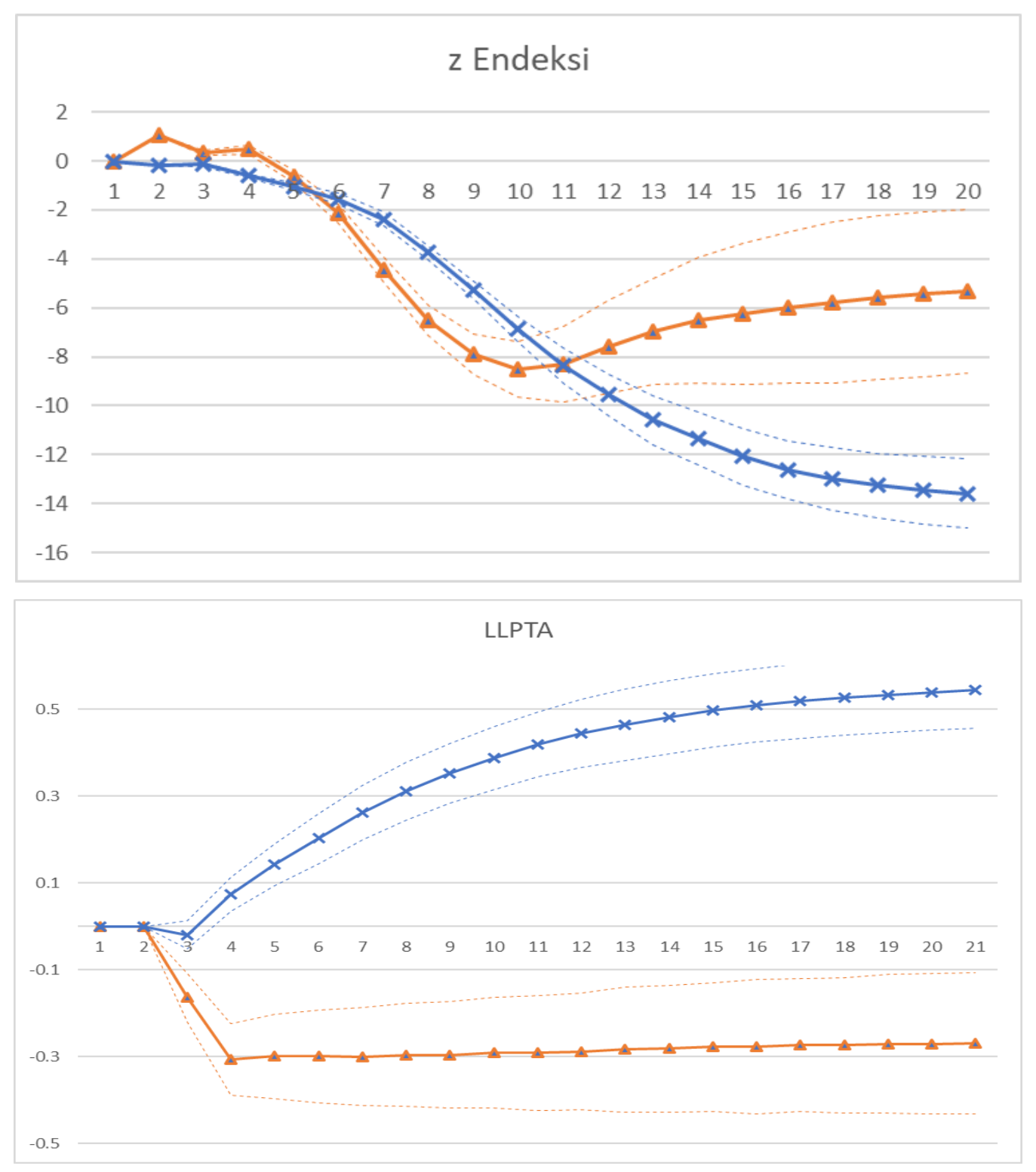

Not: Her iki grafikte turuncu ve üçgen işaretçilerle vurgulanmış çizgiler düşük faiz rejimi olarak adlandırılan birinci rejimdeki tepkileri ifade ederken, pembe kesikli çizgiler 2 standart hatalık güven aralıklarıdır. Aynı şekilde, mavi renkli ve çarpı şeklindeki işaretçiler ile vurgulanmış çizgiler yüksek faiz rejimi olarak adlandırılan ikinci rejimdeki tepkileri ifade eder ve mavi renkli kesikli çizgiler 2 standart hatalık güven aralıklarıdır. 
Öte yandan çalışmada kullanılan bir diğer risk ölçütü ise LLPTA ölçütüdür. Her banka için hesaplanan LLPTA ölçütünün ağılıklı olarak oluşturduğu risk faktörünün faiz artışına tepkileri yine Şekil 2' de ikinci satırda takip edilebilmektedir. Buna göre, genişletici para politikasının LLPTA ölçütü açısından etkilerinin faiz rejimine bağı olarak değiştiği görülmektedir. Faiz oranının \%6,6'nın altında kaldığı birinci rejimde, faiz düşüşü banka riskliliğinde azalma meydana getirmektedir. Düşük faiz ortamında faizlerde meydana gelecek bir standart hata düzeyindeki düşüşün bankaların kredi karşılıklarının toplam varlıklarına oranını 0,3 puan azalttığı gözlemlenmektedir. Yüksek faiz rejiminde ise, faizlerdeki düşüşün LLPTA cinsinden ölçülen risk faktörüne etkisi pozitiftir. Bu rejim içerisinde faiz düşüşü bankaların risklerinde artış meydana getirmektedir. Bu etki risk alma kanalının düşük faiz ortamında işlediğini ima etmektedir. Özetle, düşük faiz rejiminde faiz düşüşü toplam kredilerin artışı ve banka varlıklarının değerlerinin artması nedeniyle LLPTA cinsinden ölçülen risklerde düşük gözlemlenmesine neden olsa da yüksek faiz rejimine geçiş ile birlikte kredilerin geri ödememe riskinin artması risklerin artışına yol açmaktadır (Alzuabi vd., 2017: 18). Bu iki sonuç birlikte incelendiğinde risk kanalının çalıştığı sonucuna ulaşılmaktadır. Bu sonuç da Adanur Aklan vd. (2014) ve Özşuca ve Akbostancı (2016) çalışmalarında elde edilen sonuçlarla benzerlik göstermektedir.

Diğer faktörlere ilişkin sonuçlara ise Şekil 3'te yer verilmiştir.

Şekil 3. Faktörlerin Kümülatif Etki Tepki Grafikleri

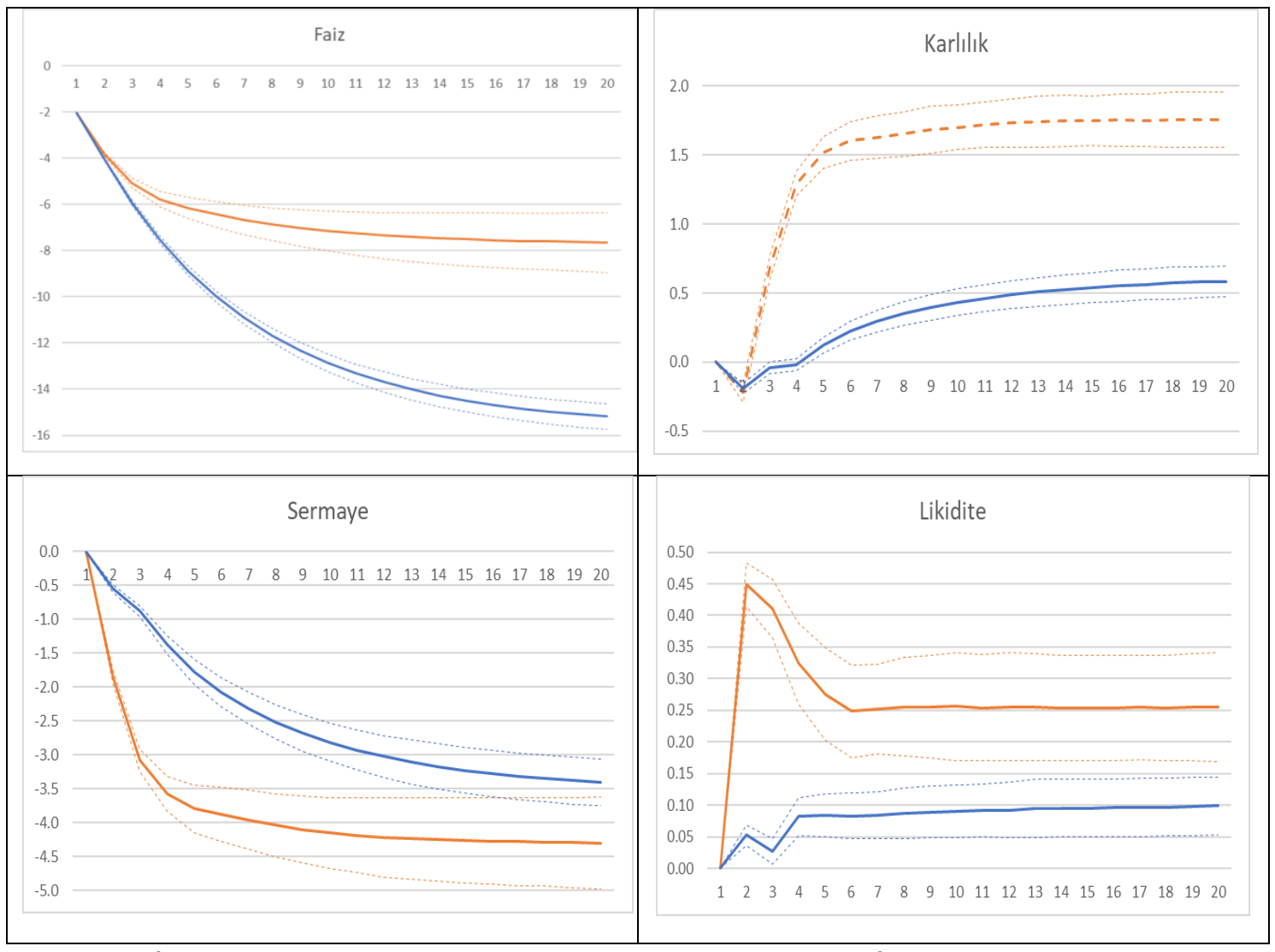

Not: Tüm grafiklerde turuncu ve üçgen işaretçilerle vurgulanmış çizgiler düşük faiz rejimi olarak adlandırılan birinci rejimdeki tepkileri ifade ederken, pembe kesikli çizgiler 2 standart hatalık güven aralıklarıdır. Aynı şekilde, mavi renkli ve çarpı şeklindeki işaretçiler ile vurgulanmış çizgiler yüksek faiz rejimi olarak adlandırılan ikinci rejimdeki tepkileri ifade eder ve mavi renkli kesikli çizgiler 2 standart hatalık güven aralıklarıdır.

Bu sonuçlara göre, karlıık ile faiz arasındaki ilişkinin rejimlere göre farklılaştığını söylemek mümkündür. Düşük faiz ortamında faizde meydana gelen bir düşüşün karlılık üzerinde ilk iki dönemde negatif etkisi gözlenirken, üçüncü dönemden itibaren kuvvetli biçimde pozitif etkisi bulunmaktadır. Yüksek faiz rejiminde ise faiz düşüşü bankalar için çok daha düşük düzeyde karlıık artışına neden olmaktadır. Sermaye oranına ilişkin olarak ise, her iki rejimde de faiz oranı azalışının sermaye oranını azalttığı savunulabilir. Son 
olarak, faiz düşüşü bankaların likidite oranını düşük ve yüksek faiz rejimlerinde arttırmaktadır. Ancak düşük faiz rejimindeki likidite artışı çok daha kuvvetlidir. Bir başka deyişle, düşük faiz ortamında meydana gelen bir faiz artışı likiditeyi gecikmeli olarak arttırmaktadır. Faizlerde meydana gelen negatif şokun etkileri tüm değişkenler üzerinde her iki rejimde de istatistiki olarak anlamlıdır.

Türkiye ekonomisinde para politikasının risk kanalının işlediğine dair bulgular örnekleme dahil edilen bankaların ortak bir risk faktörü üzerinden yorumlanmıştır. Bununla birlikte veri setinde yer alan tüm bankaların risk ölçütlerinin genişletici para politikasından nasıl etkilendiğini izlemek mümkündür. Şekil 4 tüm bankaların her iki rejimde bankalar arası piyasada meydana gelen faiz düşüşüne risk faktörlerinin tepkisini içermektedir. Ekler bölümünde yer alan Tablo A.1 bankaların varlık, sermaye ve likidite değişkenlerine göre durumunu ve sahiplik açısından durumunu ifade etmektedir. Varlık büyüklüğü, likidite ve sermaye güçlülüğü sektör ortalamasına göre gruplandırılmıştır. Illgili karakteristiklerde sektör ortalamasının üstünde yer alan bankalar büyük/yüksek sınıfına dahil edilmiştir.

Şekil 4. Tüm Bankaların Z-Endeksinin Kümülatif Etki Tepki Grafikleri

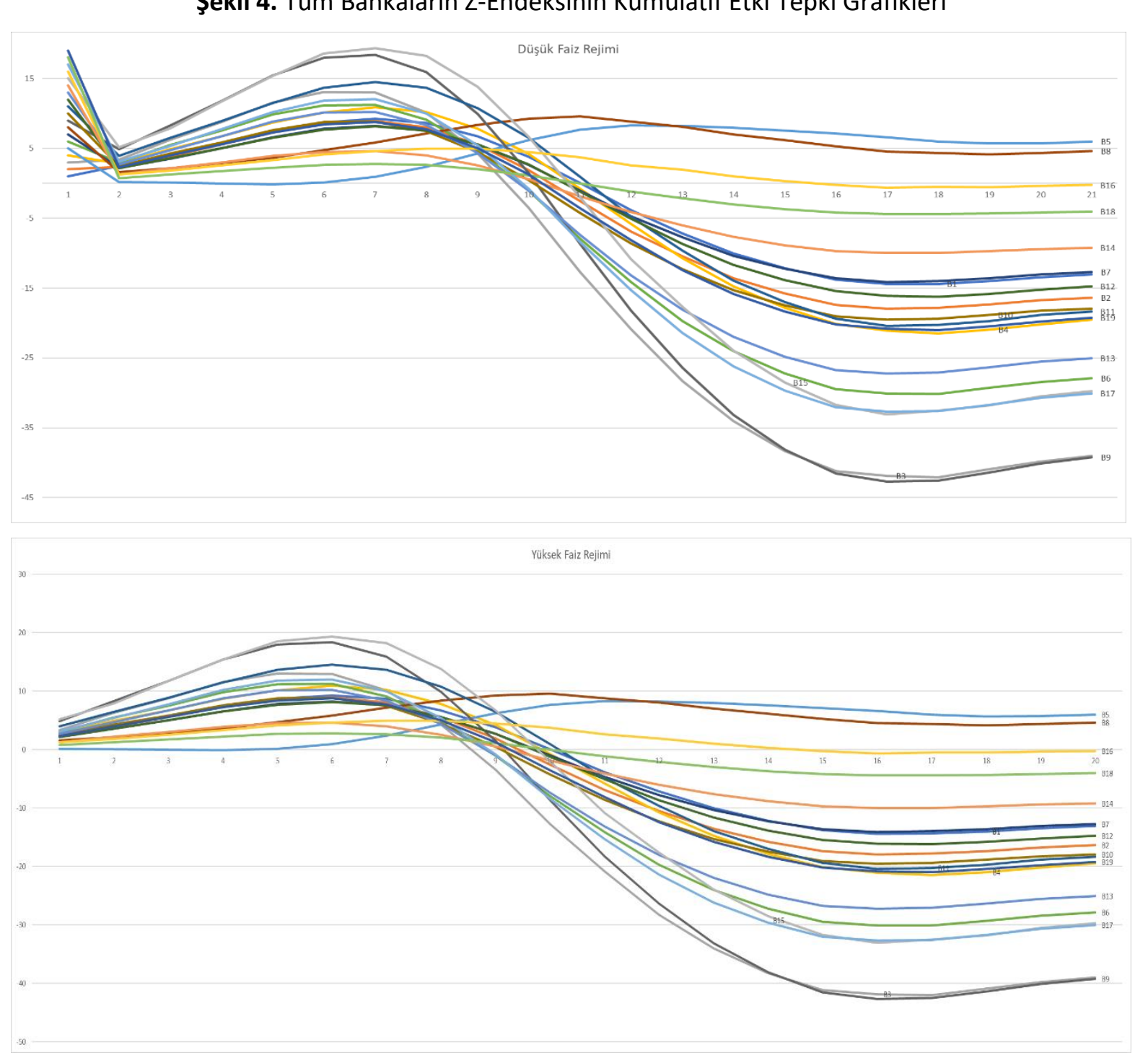

Bu sınıflandırmaya göre, varlık büyüklüğü kriterine göre B1, B4, B6, B7, B10, B11, B12, B14, B17, B18 ve B19 kodlu bankalar büyük banka kategorisine dahildir. Ancak varlıklarına göre büyük bankalar ile küçük bankaların risk tepkileri arasında Şekil 4 anlamlı bir farklılık sunmamaktadır. Kim (2014)'de çalışmasında bankanın varlık büyüklüğü ile riskliliği arasında anlamlı bir ilişki bulamamıştır. Ancak, Lopez vd. (2011) ise 
düşük faiz dönemlerinde büyük bankaların daha az risk aldıklarına, Altunbas vd. (2010) ise büyük bankaların daha fazla risk aldıklarına yönelik kanıtlar elde etmiştir.

Benzer şekilde, listedeki bankalardan B1, B3, B5, B8, B9, B11, B15 ve B16 yüksek sermaye oranına sahip bankalardır. Yine Şekil 4'de bankaların sermaye büyüklüklerinin, risk tepkilerinde anlamlı bir ayrıma neden olmadığı görülmektedir. Elde edilen bu sonuçlar sermayesi güçlü bankaların daha az risk aldıklarına yönelik kanıtlar elde eden Gambacorta (2009), Kim (2014) ve Karapetyan (2016) çalışmalarıyla ayrışmaktadır.

Son olarak, B1, B3, B6, B7, B11, B13, B17 ve B19 yüksek likiditeye sahip bankalar olsalar da bu durumun tepkilerde ayırıcı bir duruma neden olduğunu söylemek mümkün değildir. Özetle, banka büyüklüğü, sermaye büyüklüğü ve likidite değişkenlerinin Türkiye'de bankacılık sektöründe risk alma davranışı üzerinde anlamlı bir etkiye sahip olmadığı savunulabilir. Gambacorta (2009) ve Köhler (2012) düşük faiz dönemlerinde daha likit varlıklara sahip bankaların riskliliğinin daha az olduğu sonuçlarına ulaştığından, çalışmamızdan elde edilen sonuçlar adı geçen çalışmalarla farklılaşmaktadır.

Ayrıca, Özşuca ve Akbostancı (2016) ve Adanur ve Aklan vd. (2014) Türkiye için para politikasının bankaların risk alma kanalının incelendiği çalışmalarda varlık büyüklüğü, sermaye güçlülüğü ve likit varlıklara sahip olunmasının bankalar açısından düşük faiz dönemlerinde daha fazla risk anlamına geldiğine yönelik sonuçlar elde ettiğinden, çalışmamızda elde edilen sonuçlar banka özellikleri bazında farkılaşmaktadır. Çalışmamızda elde edilen sonuçların literatürde Türkiye için yapılan çalışmalarla farklılaşmasının sebebinin kullanılan ampirik yöntemler olduğu söylenebilir. Ayrıca, bu bankaların büyüklük, likidite ve sermaye güçlülükleri sektör ortalamalarına göre belirlenmiştir. Dolayısıyla bankaların gruplandırılmış olması sonuçların farklılaşmasına sebep olabilecektir.

\section{Sonuç}

Para politikasının risk kanalı 2008 küresel finansal krizi sonrasında keşfedilen ve etkinliği sıklıkla tartışılan bir politika aracı olarak değerlendirilmektedir. Para politikasının risk kanalı; genişletici para politikası olarak uygulanan faiz indirimlerinin finansal piyasalarda aracı işlevine sahip bankaların risk alma tutumlarında değişime neden olduğunu iddia etmektedir. Getiri arayışındaki bankaların düşük faiz dönemlerinde risk iştahlarının artması ve daha riskli müşterilere kredi verme eğilimine sahip olması olarak tanımlanabilir. Literatürdeki risk kanalının etkinliği gelişmiş ve gelişmekte olan ülkeler için incelenmiş olmakla birlikte, Türkiye'de risk kanalına ilişkin çalışmalar kısıtıdır. Bununla birlikte, çalışmalarda kullanılan tahmin yöntemleri beraberinde önemli kısıtlar getirmektedir. Çalışmaların neredeyse tamamı az sayıda değişken ile risk kanalını analiz etmeye çalışmaktadır. Aynı zamanda faiz ile risk tutumu arasındaki ilişki doğrusal varsayıldığı için olası asimetriler dikkate alınmamaktadır. Bu çalışma, FAVAR yöntemini eşikli olarak modelleyerek hem geniş bir veri seti ile çalışma imkanına hem de farklı faiz rejimlerinde faiz-risk ilişkisinin asimetrik olmasına izin vermektedir. Literatürde ilk defa kullanılan T-FAVAR yöntemi sayesinde literatürü bahsedilen yönlerde geliştirmeyi hedeflemektedir.

Çalışmanın bulguları, Türkiye'de bankacılık sektörüne ait bilanço verilerini ve makro iktisadi değişkenleri kullanarak 2003 sonrası dönemde risk kanalının etkin ve güçlü biçimde çalıştığını göstermektedir. Çalışmada literatürde sıklıkla kullanılan iki tip risk ölçütü kullanılış̧ır. Bunlardan biri kredi karşııılarını bankaların toplam varlıkları ile birlikte dikkate alan LLPTA iken diğeri banka varlıklarındaki getirileri ve getirilerin oynaklığını dikkate alan z endeksidir. Her iki risk ölçütü de risk kanalının geçerli olduğu sonucunu doğrulamaktadır.

Çalışmanın rejimlere ilişkin bulguları Türkiye'de para politikasının 2008 küresel finansal krizi ile birlikte değişime uğradığını göstermektedir. Bankalar arası piyasada gecelik faizin eşik değerden düşük olduğu gözlemler büyük ölçüde 2008 krizinin hemen sonrasındaki dönemde izlenmektedir. Dolayısıyla, küresel krizin Türkiye ekonomisi için bir düşük faiz rejimi yarattığı sonucuna ulaşılabilir. Bu değişikliğin büyük ölçüde likidite koşullarına bağlı olarak dış kaynaklı olduğu tahmin edilmektedir. Kriz sonrasında gelişmiş ülke ekonomilerinde izlenen toparlanma politikalarının genişlemeci karakterde olduğu ve piyasalardaki likiditeyi arttırdığı bilinmektedir. Küresel likidite koşullarında ortaya çıkan iyileşmenin Türkiye ekonomisi için kriz sonrasındaki geçici bir dönemde düşük faiz rejimi yaratarak bir fırsat penceresi açtığı savunulabilir. Bu dönemde TCMB'nın 
iktisadi büyümeyi desteklemek amacıyla kredi büyümesini teşvik etme yönündeki politikaları, likidite artışının radikal biçimde artan kredi hacmi ile beraber bankaların risk tutumları üzerinde etkili olmuştur. Artan likidite risk artışına dönüşmekle beraber toparlanma sürecinin sonlanmasının ardından yeniden yüksek faiz rejimine dönülmesi riskleri belirgin hale getirmiştir.

Genişletici para politikası uygulamaları faiz rejimine bağlı olarak risk tutumunu etkilemektedir. LLPTA cinsinden ölçülen risk ölçütüne ilişkin bulgular, düşük faiz ortamında faiz indirimlerinin riski azaltmasına karşın yüksek faiz ortamına geçilmesi ile birlikte geri ödeyememe riski ile karşı karşıya kalındığını ispatlamaktadır. Nitekim genişletici para politikasının düşük faiz rejiminde likidite arttırıcı etkisi daha büyüktür ve artan likidite daha riskli kredilere dönüşmektedir. Benzer sonuca z endeksi ile ulaşmak mümkündür. Riskin ters bir ölçütü olan z endeksi, her iki rejimde de faiz indirimi ile birlikte öncelikle artmakta ancak belirli bir dönem sonra kümülatif olarak azalmaktadır. Bu bulgu z endeksinin benzer bir mekanizmaya işaret ettiğini göstermektedir. Likidite artışı kredi hacminin genişlemesine neden olurken kısa vadede risklerin azaldığı gözlemlenirken, orta ve uzun vadede daha riskli müşterilere verilen kredilerin temerrüde uğramaya başlaması ile riskte önemli artışlar gözlenmektedir. Üstelik risk artışı belirli bir dönemden sonra yüksek faiz rejiminde daha belirgin hale gelmektedir.

Dolayısıyla Türkiye ekonomisi için literatürle uyumlu biçimde genişletici para politikasının risk kanalı üzerinden finansal istikrarı bozma eğiliminde olduğu sonucuna ulaşılmaktadır. Bu sonuç orta ve uzun vadede daha belirgin olarak karşımıza çıkmakla birlikte faiz düşüşlerinin istikrar bozucu etkileri yüksek faiz rejiminde daha kuvvetlidir. Politika yapıcıların büyümeyi destekleyici para politikası tasarımlarında uyguladıkları genişletici bir araç olan faiz indirimlerinin bankacılık sektörü riskleri vasıtasıyla finansal istikrarsızlık yaratma maliyeti olduğu hesaba katılmalıdır. Kredi hacmi genişlemesi ile ekonomik büyüme arasında olduğuna inanılan güçlü ve pozitif ilişkinin avantajlarından yararlanmaya çalışan politika setlerinde finansal istikrara yönelik destekleyici önlemlerin yer alması gerektiği anlaşılmaktadır.

\section{Beyan ve Açıklamalar (Declarations and Disclosures)}

Yazarların Etik Sorumlulukları (Ethical Responsibilities of Authors): Bu çalışmanın yazarları, araştırma ve yayın etiği ilkelerine uyduklarını kabul etmektedirler.

Çıkar Çatışması (Conflicts of Interest): Yazarlar tarafından herhangi bir çıkar çatışması beyan edilmemiştir.

Finansal Destek (Funding): Yazarlar, çalışmanın hazırlanması ve/veya yayınlanması sürecinde herhangi bir finansal destek almamışlardır.

Yazar Katkı Oranı (Author Contributions): Yazarlar, çalışmaya olan katkılarını şu şekilde beyan etmişlerdir: Kavramlaştırma ve çalışma dizaynı, U. Akkoç ve Ö. Özgür; verilerin toplanması, U. Akkoç ve Ö. Özgür; verilerin analizi ve sonuçların yorumlanması, U. Akkoç ve Ö. Özgür; çalışmanın ilk/taslak halinin yazılması, U. Akkoç ve Ö. Özgür; çalışmanın gözden geçirilmesi ve düzenlenmesi/düzeltilmesi, U. Akkoç ve Ö. Özgür. Çalışmanın ilk ve son hali tüm yazarlar tarafından okunmuş ve onaylanmış olup, yazarlar çalışmalarıyla ilgili sorumluluğu kabul etmektedirler.

intihal Denetimi (Plagiarism Checking): Bu çalışma, intihal tarama programı kullanılarak intihal taramasından geçirilmiştir.

\section{Son Notlar}

1. Hacıoğlu Höke ve Tuzcuoğlu (2016) tarafından önerilen eşik FAVAR modeli, faktör serilerinin elde edilmesine imkân sağlayan temel bileşen analizinde eşikli yapıyı modellemektedir. Dolayısıyla, bu çalışmada sunulan eşik FAVAR yöntemi özgünlüğünü korumaktadır.

2. Çalışmada kullanılan değişkenlerden Tablo 4'te her faktör için en yüksek faktör yüküne sahip beş adedinin korelasyon matrisine Tablo A.2'de yer verilmiștir.

3. Birim kök testi sonuçları talep edilmesi halinde yazarlardan edinilebilir. 
4. Eşik VAR modellerinin tahmin edilmesinde eşik değerin içsel olarak belirlenmesi de mümkündür. Çalışmada tutarılık kontrolü amacıyla, içsel olarak belirlenen eşik ile analizler tekrar edilmiştir. Bu durumda eşik değer \%10,2 olarak elde edilmektedir. Bu eşik değer ile yapılan analizlerde sonuçların önemli biçimde değişmediği görülmektedir.

5. Rejim 1'e ait tahmin sonuçlarının, $\% 6,6$ 'lık eşik değer ve gecikmeler dikkate alındığında küçük bir veri ile elde edildiğini belirtmek isteriz.

\section{Kaynaklar}

Adanur Aklan, N., Kanalıcı Akay, H., \& Çınar, M. (2014). Is there a risk-taking channel of monetary policy in Turkey? Marmara Üniversitesi Iktisadi ve İdari Bilimler Dergisi, 36(1), 55-67.

Adrian, T., Estrella, A., \& Shin, H. S. (2019). Risk-taking channel of monetary policy. Financial Management, 48(3), 725738.

Akıncı, D. A., Matousek, R., Radic, N., \& Stewart, C. (2012). Monetary policy and banking sector: Lessons from Turkey. Working Paper. London Metropolitan University, London, UK.

Altunbas, Y., Gambacorta, L., \& Marques-Ibanez, D. (2010). Does monetary policy affect bank risk-taking? ECB Working Paper, No. 1166.

Alzuabi, R., Caglayan, M., \& Mouratidis, K. (2017). The risk-taking channel in the US: A GVAR approach. The Sheffield Economic Research Paper Series, 201700.

Angeloni, I., Faia, E., \& Duca, M. L. (2015). Monetary policy and risk taking, Journal of Economic Dynamics and Control, 52, 285-307.

Ayaydin, H., \& Karakaya, A. (2014). The effect of bank capital on profitability and risk in Turkish banking. International Journal of Business and Social Science, 5(1), 252-271.

Bai, J., \& Ng, S. (2008). Large dimensional factor analysis. Now Publishers Inc.

Bernanke, B. S., Boivin, J., \& Eliasz, P. (2005). Measuring the effects of monetary policy: A factor-augmented vector autoregressive (FAVAR) approach. The Quarterly Journal of Economics, 120(1), 387-422.

Borio, C., \& Zhu., H. (2008). Capital regulation, risk-taking and monetary policy: A missing link in the transmission mechanism? BIS Working Papers.

Brana, S., Campmas, A., \& Lapteacru, I. (2019). (Un)Conventional monetary policy and bank risk-taking: A nonlinear relationship. Economic Modelling, 81, 576-593.

Chen, M., Wu, J., Jeon, B. N., \& Wang, R. (2017). Monetary policy and bank risk-taking: Evidence from emerging economies. Emerging Markets Review, 31, 116-140.

Colletaz, G., Levieuge, G., \& Popescu, A. (2018). Monetary policy and long-run systemic risk-taking. Journal of Economic Dynamics and Control, 86, 165-184.

De Moraes, C. O., Montes, G. C., \& Antunes, J. A. P. (2016). How does capital regulation react to monetary policy? New evidence on the risk-taking channel. Economic Modelling, 56, 177-186.

De Santis, R. A, \& Surico, P. (2013). Bank lending and monetary transmission in the Euro area. Economic Policy, 28(75), 423-457.

Delis, M. D., Hasan, I., \& Mylonidis, N. (2017). The risk-taking channel of monetary policy in the US: Evidence from corporate loan data. Journal of Money, Credit and Banking, 49(1), 187-213.

Faia, E., \& Karau, S. (2019). Banks' systemic risk and monetary policy. Centre for Economic Policy Research, 1-30.

Gaggl, P., \& Valderrama, M. T. (2010). Does a low interest rate environment affect risk taking in Austria? Monetary Policy and the Economy, 4(4), 32-48.

Gambacorta, L. (2009). Monetary policy and the risk-taking channel. BIS Quarterly Review, December, 43-53.

Hacioglu Hoke, S., \& Tuzcuoglu, K. (2016). Interpreting the latent dynamic factors by threshold FAVAR model. Bank of England Working Paper No. 622.

Huey, T. T., \& Li, D. C. S. (2016). Measuring bank risk-taking behaviour-the risk-taking channel of monetary policy in Malaysia. Bank for International Settlements Working Paper.

Kang, L., Guo, R., \& Zhang, M. (2019). The risk-taking channel and monetary transmission mechanisms in China. Asian Economic and Financial Review, 9(12), 1358-1367. 
Karapetyan, A. (2016). The risk-taking channel of monetary policy in Norway. Norges Bank, Oslo Working Paper, No. $5 / 2016$.

Kashyap, A. K., \& Stein, J. C. (1995). The impact of monetary policy on bank balance sheets. Carnegie-Rochester Conference Series on Public Policy, 42, 151-195.

Kim, M. (2014). The risk-taking channel of monetary policy in Korea. Korea and the World Economy, 15(3), 447-473.

Koop, G., Pesaran, M. H., \& Potter, S. M. (1996). Impulse response analysis in nonlinear multivariate models. Journal of Econometrics, 74(1), 119-147.

Köhler, M. (2012). Which banks are more risky? The impact of loan growth and business model on bank risk-taking. Deutsche Bundesbank Discussion Paper, No 33/2012.

López, M., Tenjo, F., \& Zárate, H. (2011). The risk-taking channel and monetary transmission mechanism in Colombia. Ensayos Sobre Política Económica, 29.

Montes, G. C., \& Peixoto, G. B. T. (2014). Risk-taking channel, bank lending channel and the paradox of credibility, evidence from Brazil. Economic Modelling, 39, 82-94.

Neuenkirch, M., \& Nöckel, M. (2018). The Risk-taking channel of monetary policy transmission in the Euro area. Journal of Banking \& Finance, 93, 71-91.

Özşuca, E. A., \& Akbostancı, E. (2016). An empirical analysis of the risk-taking channel of monetary policy in Turkey. Emerging Markets Finance and Trade, 52(3), 589-609.

Paligorova, T., \& Santos, J. A. (2017). Monetary policy and bank risk-taking: Evidence from the corporate loan market. Journal of Financial Intermediation, 30, 35-49.

Rajan, R. G. (2006). Has finance made the world riskier? European Financial Management, 12(4), 499-533.

Sarkar, S., \& Sensarma, R. (2019). Risk-taking channel of monetary policy: Evidence from Indian banking. The Journal of Applied Economic Research, 13(1), 1-20.

Zhou, S., \& Tewari, D. D. (2019). Shadow banking, risk-taking and monetary policy in emerging economies: A panel cointegration approach. Cogent Economics \& Finance, 7(1), 1636508. 


\section{Ekler}

Tablo A.1. Banka Listesi

\begin{tabular}{lccc}
\hline Banka Adı & Varlık Büyüklüğü & Sermaye Düzeyi & Likidite \\
\hline B1 & Büyük & Yüksek & Yüksek \\
B2 & Küçük & Düşük & Düşük \\
B3 & Küçük & Yüksek & Yüksek \\
B4 & Büyük & Düşük & Düşük \\
B5 & Küçük & Yüksek & Düşük \\
B6 & Büyük & Düşük & Yüksek \\
B7 & Büyük & Düşük & Yüksek \\
B8 & Küçük & Yüksek & Düšük \\
B9 & Küçük & Yüksek & Düşük \\
B10 & Büyük & Düşük & Düşük \\
B11 & Büyük & Yüksek & Yüksek \\
B12 & Büyük & Düşük & Düşük \\
B13 & Küçük & Düşük & Yüksek \\
B14 & Büyük & Düşük & Düşük \\
B15 & Küçük & Yüksek & Düşük \\
B16 & Küçük & Yüksek & Düşük \\
B17 & Büyük & Düşük & Yüksek \\
B18 & Düşük & Düşük \\
B19 & Büyük & Düşük & Yüksek \\
\hline \hline
\end{tabular}




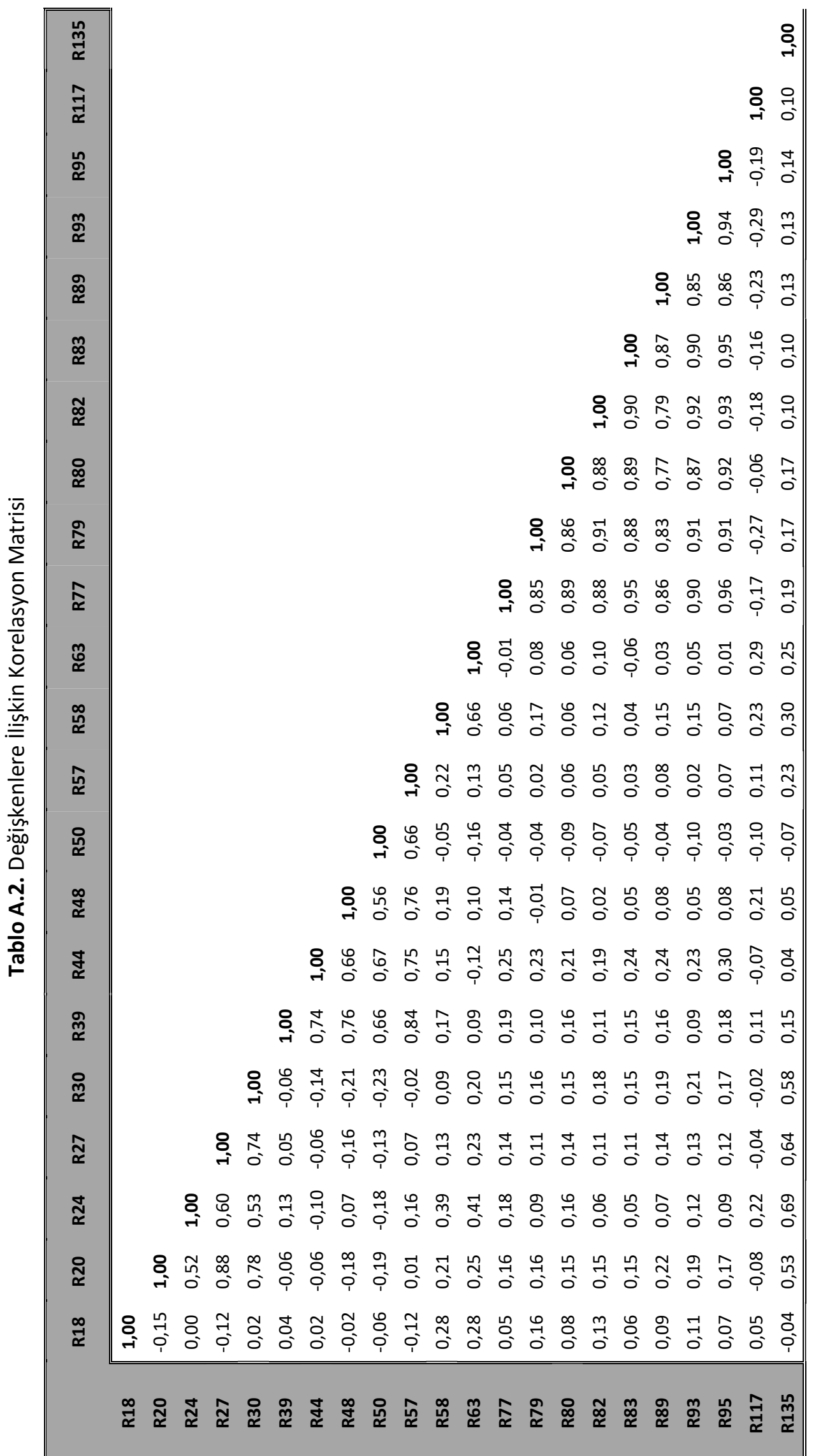


This Page Intentionally Left Blank 